\title{
多視点画像を用いたバーチャルクレイモデリングシステム
}

\section{Virtual Clay Modeling System using Multi-viewpoint Images}

\author{
上田悦子†, \\ 藪上勝 宏胡, \\ 松 本 吉 央 $^{\dagger}$, \\ 小笠原司
}

Etsuko Ueda ${ }^{\dagger}$, Katsuhiro Yabugami ${ }^{\dagger \dagger}$, Yoshio Matsumoto ${ }^{\dagger}$ and Tsukasa Ogasawara ${ }^{\dagger}$

\begin{abstract}
This paper proposes a "non-contact virtual clay modeling system." We developed a prototype of a threedimensional modeling system that allows users to shape "virtual clay" with their hand movements. In our proposed method, the users hand movements are observed with multiple cameras to estimate their positions. The human hand surface and the virtual clay are modeled by using subdivision surface. Using the estimated hand posisions, the virtual clay is shaped based on a direct free-form deformation technique. To achieve faster processing speed, we implemented the proposed system on a PC cluster. This implemented system proves the feasibility of an intuitive virtual clay modeling system.
\end{abstract}

キーワード : バーチャルクレイ, 多視点画像, サブティビジョンサーフェス, FFD, 手形状推定

\section{1.はじめに}

近年のコンピュータシステムの発展に伴って, コンピュー タ上での形状表現は 2 次元から 3 次元へと移ってきたが， マウスやトラックボールなどの従来のポインティングデバ イスでは, ディスプレイ上での 2 次元的な動きしか入力で きないため, 3 次元形状を直感的に操作することが困難で あった．そのため，3 次元形状操作を直感的に行うことが できるインタフェースの一つとして，仮想空間にモデル化 された粘土をユーザの手動作で変形する, バーチャルクレ イモデリングに関する研究が数多くされている.

従来のバーチャルクレイモデリングシステムでは，3 次元 入力装置としてデータグローブやポジションセンサ, フォー スフィードバックデバイス (PHANToM など) を利用して いるものが多い．松宮らの開発した 3 次元モデリングシス テムは，バーチャルクレイをデータグローブで計測された手 形状により変形している ${ }^{1)}$. McDonnell らは PHANToM を用いた，リアルタイム仮想彫刻システムを開発した ${ }^{2)}$. Debunne らもまたPHANToM を用いて塑性体の変形を行 うシステムを開発している ${ }^{3)}$. しかし，これらの 3 次元入 力装置は，いずれもユーザの手に装着して，指先位置や指

2004 年 11 月 4 日受付, 2004 年 7 月 20 日再受付, 2004 年 10 月 14 日 採録

†奈良先端科学技術大学院大学 ロボティクス講座

( $\bar{T}$ 629-0192 祭良県生駒市高山町 8916-1, TEL 0743-72-5373) †十株式会社 島津製作所

( $=$ 604-8511 京都市中京区西)京桑原町 1 番地)

$\dagger$ Nara Institute of Science and Technology, Robotics Laboratory

(8916-1, Takayama-cho, Ikoma-shi, Nara 639-0192, Japan)

$\dagger \dagger$ Shimadzu Corporation

(1, Nishinokyo-Kuwabara, Nakagyo-ku, Kyoto 604-8511, Japan)

映像情報メディア学会誌Vol. 59, No. 1, pp. 123〜129（2005）
の関節角度を計測する “接触型” の計測装置であり，ユーザ の動作に制限を与え，拘束感を感じさせやすいという久点 を持っている.さらに, データグローブやフォースフィー ドバックデバイスは，高価な上に使用目的も限定されてし まう。

我々は，設計の実務環境で用いられる 3 次元形状操作シ ステムのインタフェースは，非接触であることが望ましい と考えている．本論文では，非接触型計測装置による 3 次 元位置入力方法として “手の 3 次元形状推定”を用いたバー チャルクレイモデリングシステムの提案を行う。従来の 3 次元入力手法との大きな違いは，代表的な非接触センサで あるカメラを複数台用いて， 3 次元位置入力を行うことで あり，ユーザの拘束感が少ないシステム構築が期待できる. さらに，一般的な CCD カメラを使用しており，3 次元位 置入力のためだけのデバイスに比べて，比較的安価にイン タフェースを構築できるというアドバンテージがある。

\section{2. システムの概要}

\section{1 システムの要件}

Quekらは, ヒューマンコンピュータインタラクションの 観点から意識的な手動作を，把持や形状作成などの操作的 な手動作と，手話などの対話的な手動作に分類している ${ }^{4)}$. Quek の分類方法に従って図 1 に示す実際の人間の手動作 例を分類すると，“じゃんけん”が対話的な手動作に，“物 体把持”，“粘土細工”，“ろくろによる形状作成”が操作的 な手動作に分類される.このように手動作の分類を行った 上で，それぞれ 30 秒程度の手動作時における右手の関節 角度の変化を，データグローブを用いて 10 人分計測した。 サンプリング周波数の違いによる, 寸べての動作の種類 


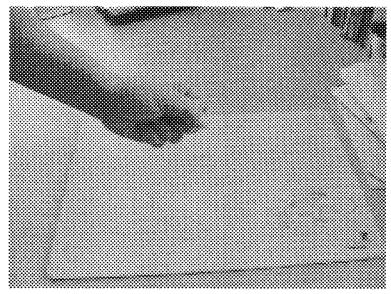

じやんけん

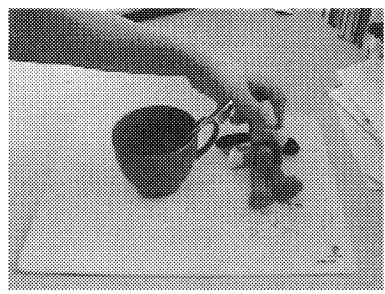

物体把持

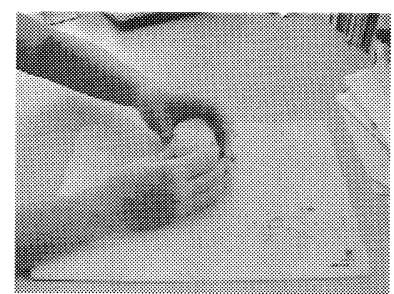

粘土細工

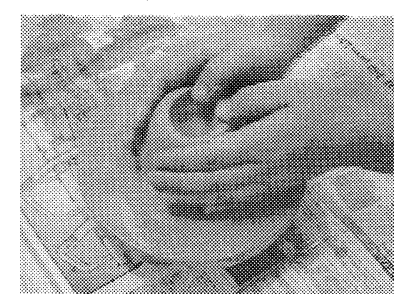

ろくろによる形状生成

図 1 手動作 $O$ 例

Examples of human hand movement.

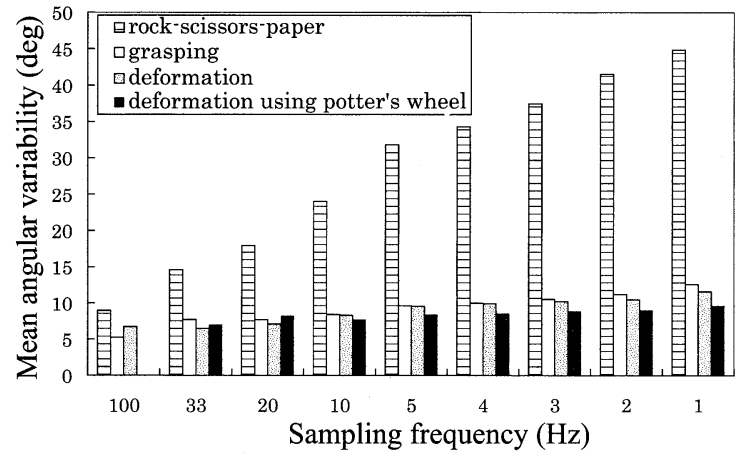

図 2 右手示指 MP 関節平均屈曲角度変化 Mean flexion angle of MP-joint at index finger.

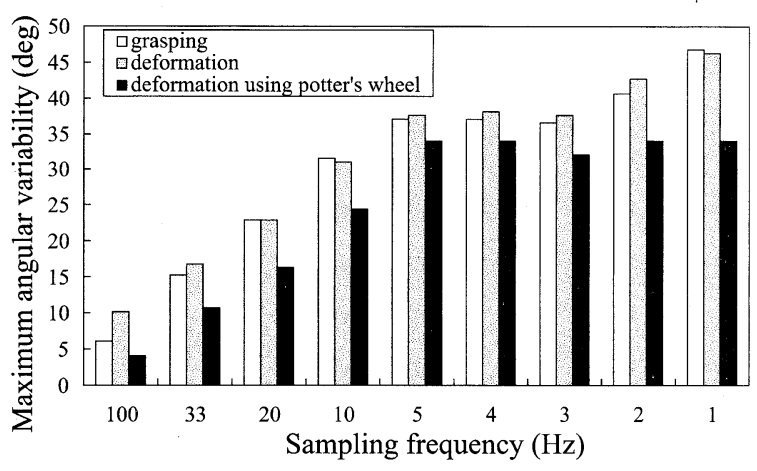

図 3 右手示指 MP 関節最大屈曲角度変化 Max flexion angle of MP-joint at index finger.

に抢ける示指 MP 関節屈曲角度の变化の平均値 $(5[\mathrm{deg}]$ 以 下の変化は変化 $0[\mathrm{deg}]$ とする）を図 2 に示す，対話的な 手動作の一種であるじゃんけんについては, どのサンプリ ング周波数においても, 関節角度の変化が飛びぬけて大き いことが分かる.これは，操作的手動作時に比べて，対話 的手動作時における右手示指 MP 関節角度は, 早くかつ大 きく変化することを示している，次に図 3 に，じゃんけん 以外の手動作時における示指 MP 関節屈曲角度変化の最大 值を示す，関節角度変化は，サンプリング間隔が $33[\mathrm{~Hz}]$ で あれば最大 $15[\mathrm{deg}], 20[\mathrm{~Hz}]$ では最大 $20[\mathrm{deg}]$ 程度, また $5[\mathrm{~Hz}]$ 以下の場合は最大 $35[\mathrm{deg}]$ 以上になることがわかる.

これらの計測結果は，粘土細工動作（特にろくろを用い た形状生成）であれば， $5[\mathrm{~Hz}]$ 以上の推定速度（処理サイ クル）で, $35[\mathrm{deg}]$ の関節角度変化を推定できれば, 入力セ ンサとしてカメラを用いたシステム構築が可能であること を示している.

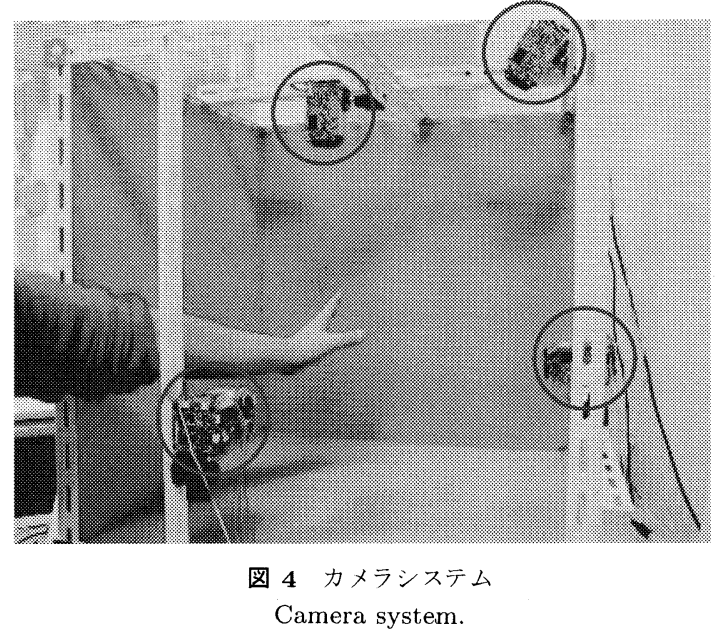

\section{2 システム構成}

手形状観測領域は，図 4 に示すような $600 \mathrm{~mm}$ 四方の空 間であり，手領域を安定して抽出するために周囲にブルー のボードを設置している.フレームには撮影カメラとして SONY 社の CCB-EX37 を 4 台マウントしてある. 処理用 PC は 1 台であり, CPU は PentiumIII 1GHz Dual プロ セッサ，メモリーは1GByteである，B878 を搭載したビ デオキャプチャボードを 4 枚用いて, 四つのカメラ画像を それぞれキャプチャしている.

\section{3 処理の流れ}

本バーチャルクレイモデリングシステムでの処理の流れ は以下の通りである。

Step1：多視点カメラシステム (4台の CCD カメラ) によ り，観測空間内の手形状をキャプチャする，得られ た画像を 2 值化し，ボクセルモデルを高速に作成 するための片側距離変換マップ 5) を作成する.

Step2: 視体積交差法によりボクセルモデルを作成する.

Step3: 3 次元モデルフィッティングにより手形状を推定 する。

Step4: 前フレームの画像により推定した手形状と, 現フ レームの画像により推定した手形状の位置・形状 の違いを基にして，手とバーチャルクレイとの干 渉チェックを行う。

Step5: direct FFD (Free Form Deformation) を用いて バーチャルクレイの表面形状全体を滑らかに変形 する. 

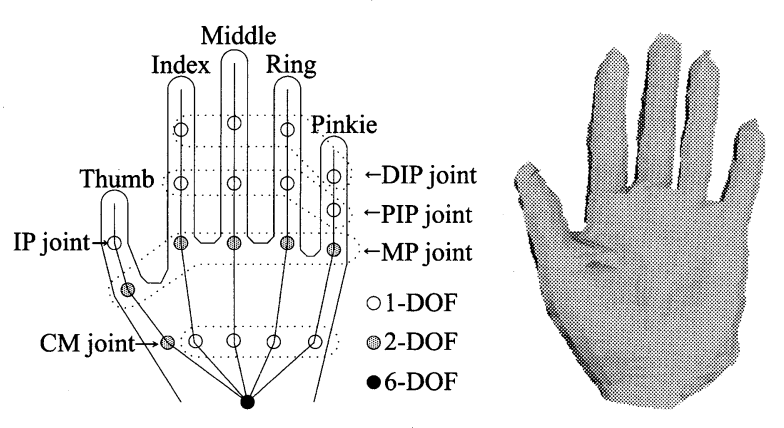

図 5 骨格モデル

Skeletal model.

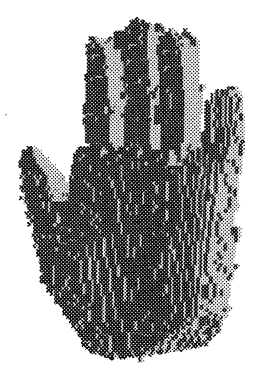

図 6 ボクセルモデル Voxel model

\section{3. 多視点カメラシステムを用いた手形状推定}

筆者らは，これまでに多視点シルエット画像を用いた手 形状推定手法を提案し，画像キャプチャ間で約 $50[\mathrm{deg}]$ の関 節角度変化が生じても手形状の推定が可能であることを示 した ${ }^{6)}$. 本章では, 提案アルゴリズムの概要とバーチャル クレイモデリングに応用するための改良点について述べる.

\section{1 基本アルゴリズム}

手形状推定の基本アプローチは，手を表現する 2 種類の 3 次元モデルを用いたフィッティングである. 2 種類のモデ ルのうちの一つは，あらかじめシステム内部に記述される 手のモデルである。このモデルは “骨格モデル”と呼ばれ， 図 5 に示すように，手の骨格構造を表す 31 自由度のリン クと皮膚表面形状を表すポリゴンから構成される。もう一 方のモデルは, 各視点から得られた手形状のシルエット画 像を統合して, 図 6 のように 3 次元化された観測データで あり，3 次元空間における手の占有領域を示す.このモデ ルは“ボクセルモデル”と呼ばれ，モデルフィッティング時 のターゲットデータとなる.

モデルフィッティングは, ボクセルモデルの外側に位置す る骨格モデルの皮膚を表現するポリゴンに対して, 図 7(a) に示すようにリンク方向に力ベクトルを発生させ, この力 ベクトルによって求められる関節軸に関するトルクの方向 を基に, 少しずつ関節角度を変化させることを繰り返して 実現される．各ジョイントの回転方向の決定方法を図 7(b) の場合を例にとって説明する. 図では, 頂点 $P_{1}, P_{2}$ と $P_{3}$ はボクセルモデルの外側に位置している.これらの頂点に ついて, Link-1に対して垂直方向の力 $\left(\boldsymbol{f}_{1}, \boldsymbol{f}_{2}, \boldsymbol{f}_{3}\right)$ をそれ

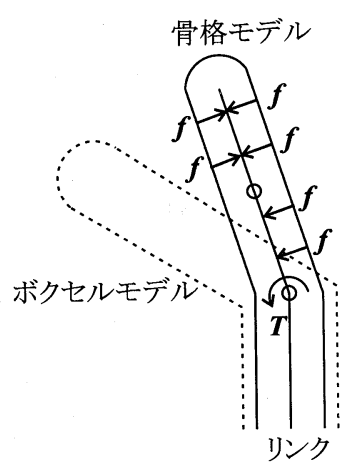

(a)

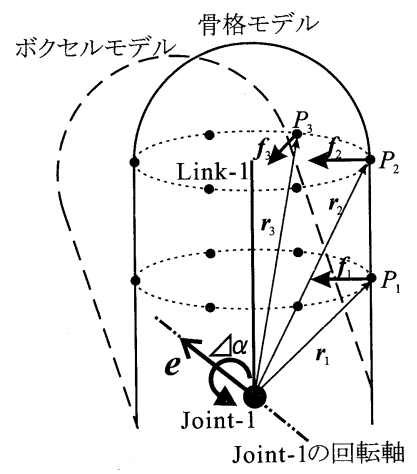

(b)
図 7 モデルフィッティングの仕組み Scheme of model fitting.

ぞれ発生させる.また，Joint-1 からこれらの頂点に向か う位置ベクトルを $\boldsymbol{r}_{1}, \boldsymbol{r}_{2}, \boldsymbol{r}_{3}$ とすると, 各頂点でのトルク は $\boldsymbol{t}_{i}=\boldsymbol{r}_{i} \times \boldsymbol{f}_{i}$ で与えられる.これらのトルク $\boldsymbol{t}_{i}$ の総和 $\boldsymbol{T}=\sum_{i} \boldsymbol{t}_{i}$ をJoint-1 に関するトルクとする. Joint-1 の回 転軸に対する回転角補正量 $\Delta \alpha$ を，このトルク $\boldsymbol{T}$ の方向 を用いて式 (1) のように決定する.

$$
\Delta \alpha=K \operatorname{sgn}(\boldsymbol{e} \cdot \boldsymbol{T})
$$

ここで $K$ は補正ゲイン, $e$ は Joint-1 の回転軸方向の単位 ベクトルである. 図 $7(\mathrm{~b})$ の場合, トルク $\boldsymbol{T}$ は Link-1 を ボクセルモデルの方向に倒すような向きを持つことになり， 結果として Link-1 は，回転軸に対して図 7(b) 内に示すよ うに, 反時計方向に $\Delta \alpha$ 度回転する. 着目している関節と リンクに関連付けられている頂点のすべてが, ボクセルモ デルの内側に位置しているとき, 着目している関節の回転 角度の推定ができたと判断する. また頂点すべてが完全に ボクセルモデルの内側に位置できない場合は, 関節角度を 推定している間にトルクの向きに振動が発生する。この振 動を検知したときは, 式 (1) 中の補正ゲイン $K$ を徐々に 小さくし，包含関係をチェックし，最終的に補正ゲインが $2[\mathrm{deg}]$ になったとき $\Delta \alpha$ の $1 / 2(1[\mathrm{deg}])$ だけ回転させ，そ の時の関節角度を, 誤差を含んだまま推定結果として取り 扱い，次のジョイントの関節角度計算に移る.

\section{2 サブディビジョンサーフェスによる皮膚形状表現}

人間の手の皮膚表面は, 骨格姿勢の変化に応じて滑らか に変形する，そのため，骨格モデルの表面形状データも骨 格姿勢の変化に応じて滑らかに変形できなければならない. 基本アルゴリズムでの手の表面形状データは，皮膚表面を 多数の小さな 3 角形のポリゴンで表現し, 各ポリゴンの形 状が骨格姿勢の変化に対応して変形できるように, ポリゴ ンの各頂点がどのリンクに対応して，その位置を変更する かをデータとして与えていた。しかし頂点間の位置関係を 考慮していないため, 関節を大きく曲げるなどの姿勢をとつ たときには，皮膚表面の滑らかな変形が保持できず，実際 の手形状と大きく違う表面形状になってしまう欠点を持っ ていた。そこで，バーチャルクレイモデリングシステムに 

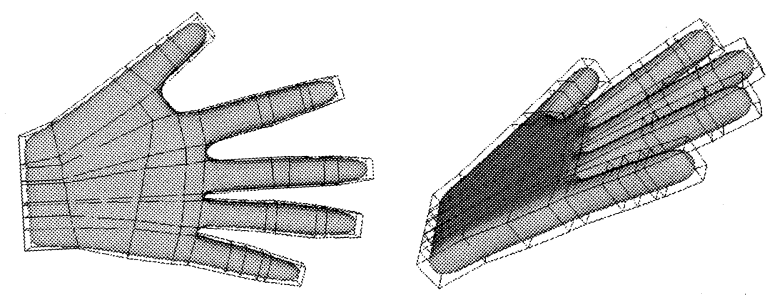

図 8 サブディビジョンサーフェスによる皮膚形状表現 Representation of hand surface using subdivision surface.

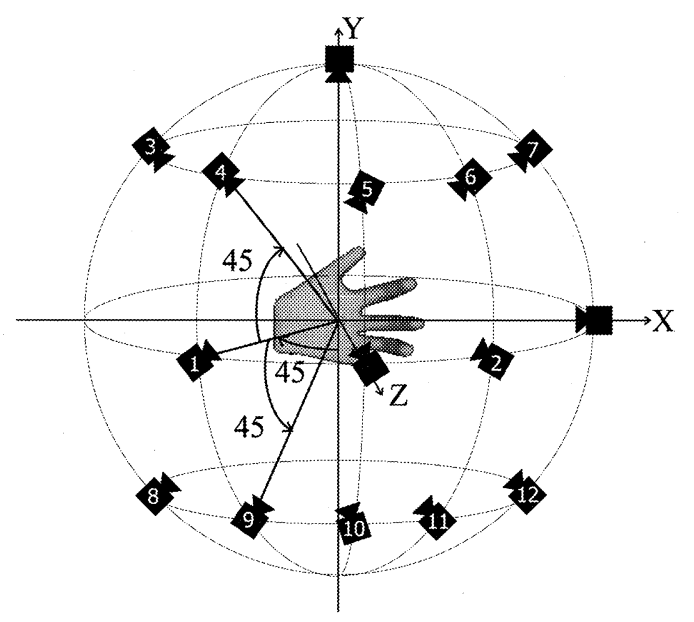

図 9 カメラの位置

Camera positions for evaluation.

実装する手形状推定では, 手の表面形状表現のためのポリ ゴン定義にサブディビジョンサーフェス $(\text { 細分割曲面 })^{7)}$ 採用した。 サブディビジョンサーフェスは, 任意のトポロ ジ一を扱える滑らかな曲面の表現方法の一つであり，一つ の曲面定義で物体表面全体の形状を定義できる．指の関節 角度変化による皮膚形状の変形を容易に表現できる。ささら に, 手の表面形状の連続性を保持しながらの変形も可能で ある。

一般にサブディビジョンサーフェスは，以下のように心゙ クトル行列の積で表現することが出来る.

$$
\boldsymbol{d}=\boldsymbol{A p}
$$

$\boldsymbol{p}=\left[p_{1}, p_{2}, \ldots, p_{n}\right]^{T}$ は初期多面体の頂点位置の集合, $\boldsymbol{d}=\left[d_{1}, d_{2}, \ldots, d_{m}\right]^{T}$ は細分割された多面体の頂点位置の 集合, 常に $n<m$ である. $\boldsymbol{p}$ は “コントロールポイント”, $\boldsymbol{d}$ は “データポイント”と呼ばれる，A は $m \times n$ の重み 行列であり，細分割のルールを表している.

実装したシステムに㧧ける手の表面形状用の初期多面体 は, 実際の手を完全に含んでしまうような粗い多面体（ポ リゴン数 120) で作成した. 式 (2)を 2 回繰り返し，1920 個の四角形ポリゴンでより滑らかに表面形状を表現してい る. 図 8 にサブディビジョンサーフェスを用いて表現した 手の表面形状データを, 初期多面体（格子表現）とあわせ て示寸. 図 5 に示した, 手の表面形状デー夕に比べて, 滑 らかな表面形状になっていることがわかる.

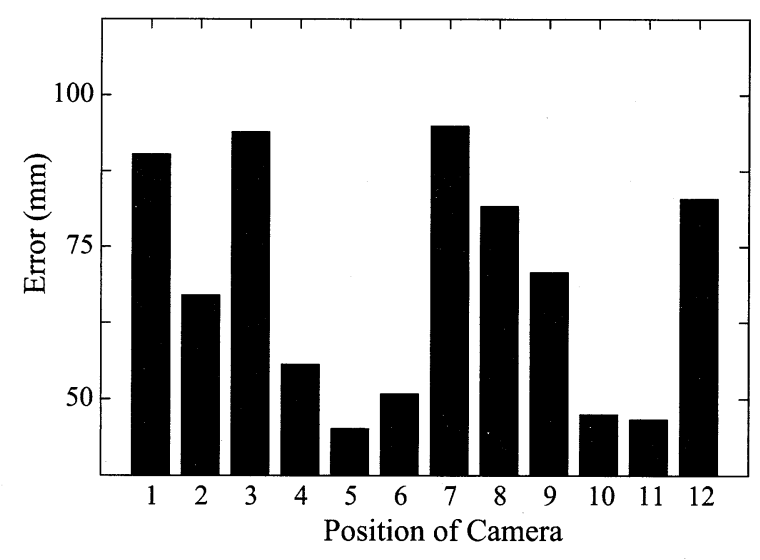

図 10 カメラの位置の違いによる平均推定誤差 Mean estimation errors for four hand poses.

\section{3 カメラ位置の決定}

2.2 節で示したシステム構成のとおり, 本研究で用いるカ メラ台数には八ードウエア構成上の制限より，現在は 4 台ま でという制限を持っている. そのため， 4 台のカメラを用い る実カメラシステムにおける, 最適なカメラ配置について シミュレーションにより評価を行った。基本のカメラ配置を 三面図を得るため正面，側面，上面の三つに決定し，もう 1 台の最適なカメラ配置を評価した．図 9 に示すように，極座 標表現を用い，手形状が原点にあるとして 4 台目のカメラ位 置を 1 12の 12 種類設定する. 設定したカメラ位置は，正 面カメラを基準とし， $\mathrm{x}-\mathrm{z}$ 平面に $90[\mathrm{deg}], 45[\mathrm{deg}],-45[\mathrm{deg}],-$ $90[\mathrm{deg}]$ とその位置から y 軸方向へ $45[\mathrm{deg}],-45[\mathrm{deg}]$ それぞ れ移動したカメラ位置である。手形状の中心からの距離は $400[\mathrm{~mm}]$ とし, カメラは原点に存在する手形状中心を向い ている.

シミュレータを用いて 4 種類の手形状を作成した．基本 のカメラ位置のシルエット画像 (3 枚) +それぞれのカメラ 位置のシルエット画像 (1 枚) の合計四つのシルエット画像 を用いて，作成した 4 種類の手形状のボクセルモデルを作 成し手形状推定を行った場合の推定誤差の平均を図 10 に 示す.ここで推定誤差は以下のように定義している.

$$
\text { error }=\sum_{i} \operatorname{dist}\left(\text { epos }_{i}, \text { tpos }_{i}\right)
$$

$e p o s_{i}$ は推定された $i$ 番目の関節の位置, $t p o s_{i}$ はシミュレー タで設定した正しい $i$ 番目の関節の位置, $\operatorname{dist}\left(\right.$ epos $_{i}$, tpos $\left._{i}\right)$ は $\mathrm{epos}_{i}$ と $\mathrm{tpos}_{i}$ の間のユークリッド距離である.

このグラフから，実験に使用した 4 種類の手形状におい ては, カメラ位置 $=5$ (正面カメラと上面カメラの間 $45[\mathrm{deg}]$ にカメラを配置）した場合に，最も推定誤差が少なくなる と言う結果が得られた。この評洒結果を用いて, 4 台のカ メラの配置は図 4 に示寸ように決定している. この多視点 カメラシステムにより推定した手形状の例を図 11 に示す. 正面カメラに正対する手姿勢の際の手形状推定において概 ね正しい推定結果が得られていることが示されている. 


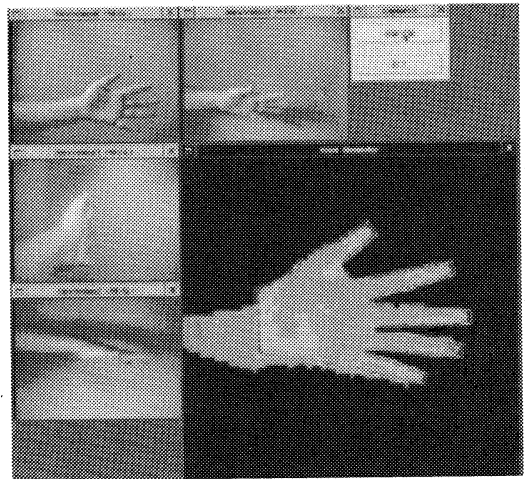

(1) $0.0 \mathrm{sec}$

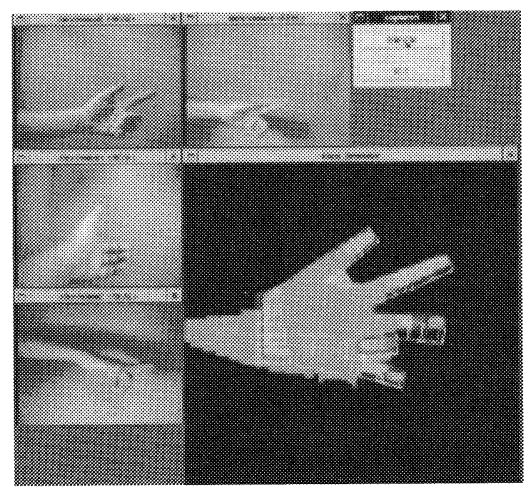

(2) $8.0 \mathrm{sec}$

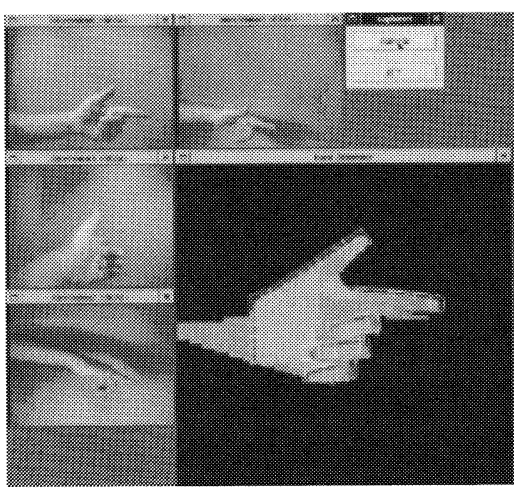

(3) $16.0 \mathrm{sec}$

図 11 手形状推定結果例

Example of hand pose estimation result using real images.

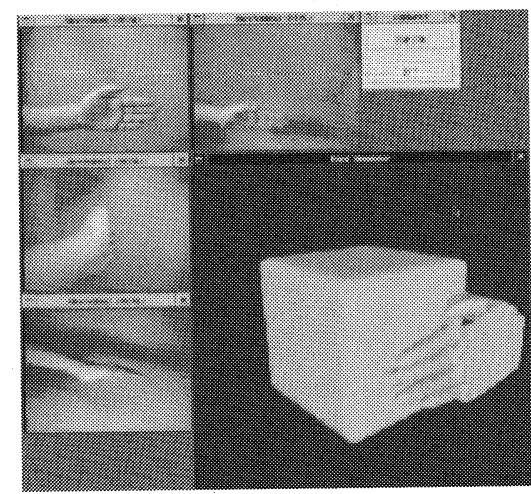

(1) $0.0 \mathrm{sec}$

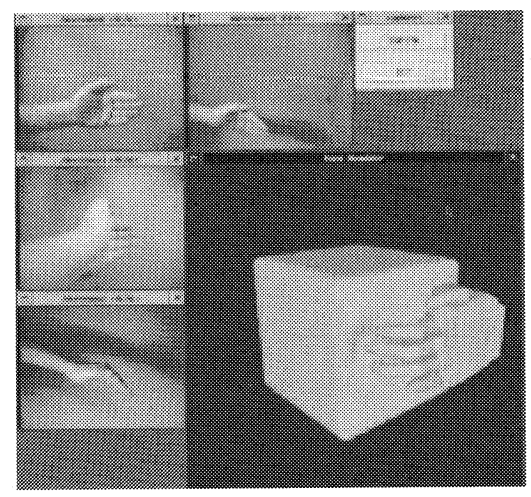

(2) $3.0 \mathrm{sec}$

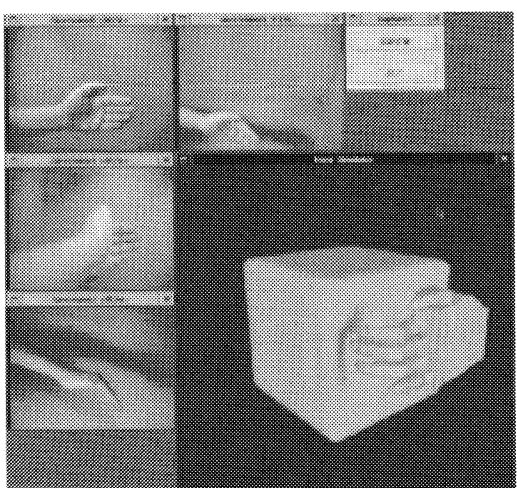

(3) $6.0 \mathrm{sec}$

図 12 指先によるバーチャルクレイの変形

Deformation of virtual clay using fingertip

\section{4. バーチャルクレイモデリングシステムの実装}

\section{1 バーチャルクレイモデルの変形}

本システムでは, 仮想空間中の粘土もまた 3.2 節で示し たサブディビジョンサーフェスよってモデル化している. 式 (2) の $\boldsymbol{d}$ で表されるバーチャルクレイのデータポイン トが，ユーザのオペレーションによって変形された場合に は，その周辺も滑らかに変形するように形状全体を再計算 する必要が生じる，我々は，滑らかな粘土形状変形をシミュ レートするために, Hsu が提案した形状表面を直接操作す るFFDによる滑らかな形状変形の手法 “direct FFD”8) を 採用し，実装している。

多視点カメラシステムを用いた手形状推定と, サブディ ビジョンサーフェスを用いて表現したバーチャルクレイを ベースとして実装した, バーチャルクレイモデリングシス テムによるクレイの変形結果を示す. 図 12 に，指先によ るバーチャルクレイの変形例を示す。また, 図 13 に, バー チャルクレイを $200[\mathrm{~ms}]$ 毎に $2[\mathrm{deg}]$ の速度で $\mathrm{y}$ 軸回りに時 計方向に回転させ, 回転ごとに各時刻におうる推定手形状 との接触判定を行い, バーチャルクレイのデータポイント の位置を変更させて, バーチャルクレイの滑らかな変形を 行った例を示す.

現システムでの 1 回のキャプチャ画像によるクレイ変形の
処理時間は, 約 $370[\mathrm{~ms}](2.7 \mathrm{~Hz})$ である. 内訳は画像キャプ チャと前処理に約 $100[\mathrm{~ms}]$, ボクセルモデル生成に約 $50[\mathrm{~ms}]$, 手形状推定に約 $160[\mathrm{~ms}]$, クレイの変形に約 $60[\mathrm{~ms}]$ となっ ている.

\subsection{PC クラスタを用いたビデオレート処理}

提案してきたバーチャルクレイモデリングシステムの処理 速度を向上させるための手法の一つとして, PC クラスタ上 への実装を行う方法がある. 従来研究での画像処理や動作計 測のために PC クラスタを用いたリアルタイムシステムに は, 画像データベース探索の並列化による手形状推定 ${ }^{9)} や$, 人体動作の 3 次元表現 ${ }^{10)}$ ，モーションキャプチャ ${ }^{11)}$ などの 例がある. 本研究では, Score5.4 を用いて 9 台の PC(Dual Xeon 2.4GHz, Memory 1GB, GigabitEthernet) より構 成される PC クラスタシステムにこれまで提案してきたシ ステムを実装した. Xeonプロセッサの Hyper Threading 機能により，1 台のホストは四つの CPUを仮想的に持つ. また，撮影カメラには IEEE1394 カメラを用いている.

2.3 節で述べた手形状推定アルゴリズムを, Step1のビ デオキャプチャ・画像処理, Step2 のボクセルモデル作成, Step3-5 の手形状推定 ・クレイの変形, の三つの処理に分 割し, ホストのパイプライン化を行う。また, 画像処理お よびボクセルモデル作成処理においては，それぞれ担当す るホスト内で並列化を行うように，アルゴリズムを修正し 


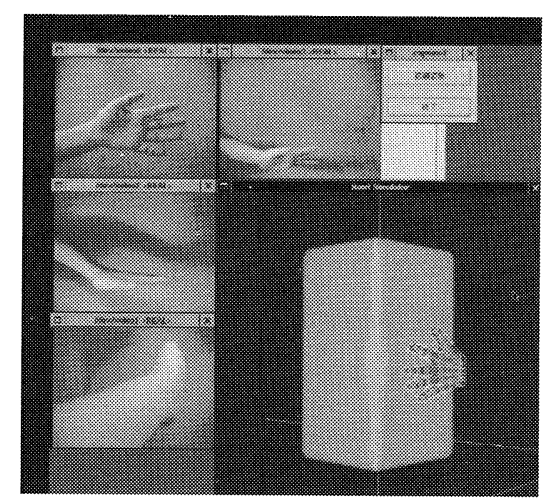

(1) $0.0 \mathrm{sec}$

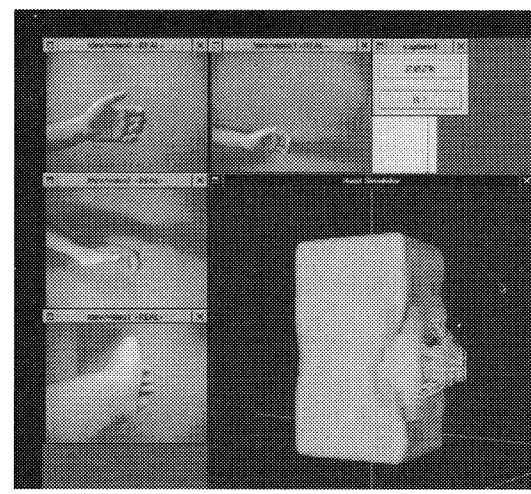

(4) $15.0 \mathrm{sec}$

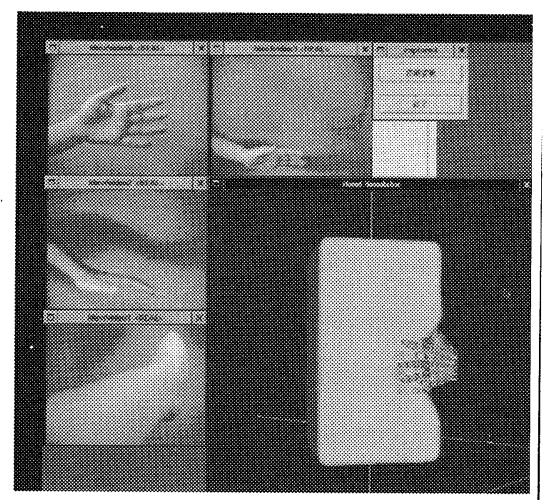

(2) $5.0 \mathrm{sec}$

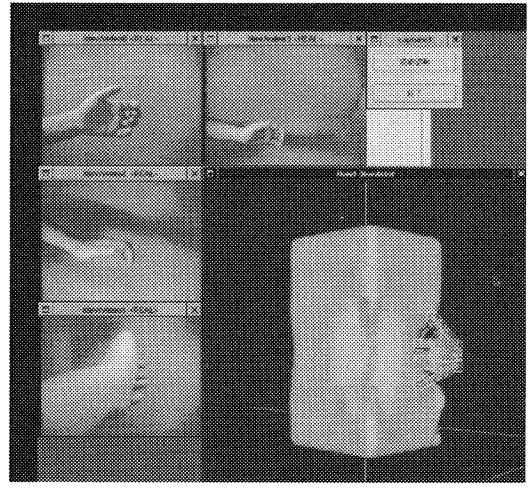

(5) $20.0 \mathrm{sec}$

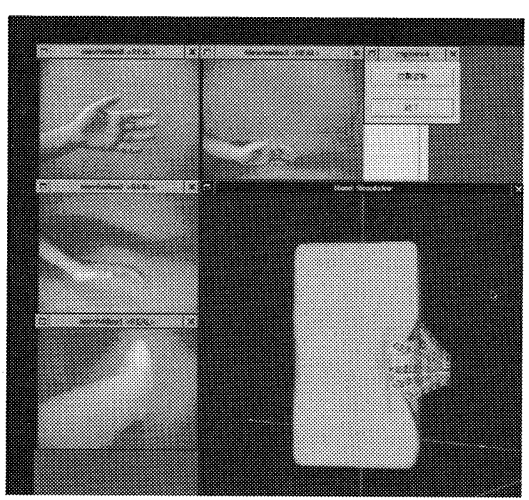

(3) $10.0 \mathrm{sec}$

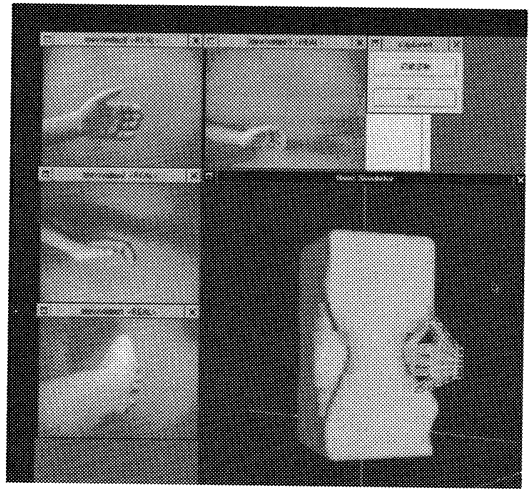

(6) $25.0 \mathrm{sec}$

图 13 ろくろを用いたバーチャルクレイの変形

Deformation of virtual clay using potter's wheel.

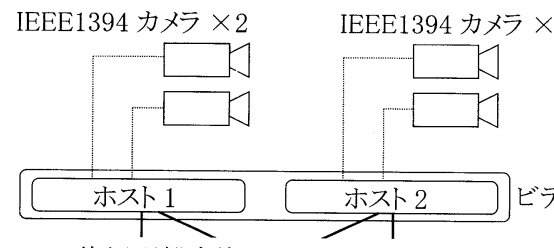

片側距離変換マップの共有

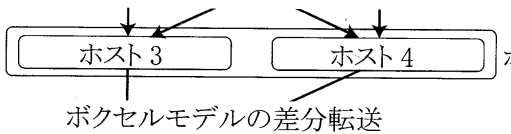

ボクセルモデルの作成

ホスト 5 手形状推定/クレイモデルの変形

図 $14 \mathrm{PC}$ クラスターの並列化実装

Implementation to PC cluster.

た．図 14 に実装したシステムの概要図を示す.

ホスト 1,2 はそれぞれが 2 台のカメラと接続されてお り, 画像のキャプチャ・画像処理を行い, 片側距離変換マッ プを作成する．画像処理は，各 CPUに各カメラの画像を 1 枚ずつ割当てることで並列化する．片側距離変換マップ はネットワークを通じてホスト 3,4 で共有される. ホスト 3，4では，それぞれのホストが四つの CPUを用いて，手 のボクセルモデルの作成を並列に行う。立方体のボクセル 空間を八つに等分割し，それぞれを八つの CPU で分担す る. ホスト 5 でフィッティング以降の処理をまとめて行う. 図 15 に処理の流れとタイムチャートを示す. ボクセルモ デルの転送が並列化による処理速度向上のボトルネックと なるが，前フレームのボクセルモデルとの差分を転送する ことで, 転送に要する時間を $6[\mathrm{~ms}]$ に抑えている.これは,
ボクセルモデルを処理せず転送したときに比べて，1/20の 転送速度の向上となった。キャプチャから推定結果の表示 まで約 $54[\mathrm{~ms}]$ かかるが，各ホストでの処理が最大 $26[\mathrm{~ms}]$ で終わっていることから，ビデオレート $(33[\mathrm{~ms}]$ 周期 $)$ で バーチャルクレイモデル変形を行うことができているとい える. PC クラスタにより, ビデオレートの手形状推定が 可能になり，粘土細工の際の手動作においては，ユーザに ストレスを感じさせない変形速度をもたらすことが可能と なった。

\section{5.おわりに}

本論文では，3 次元形状を直感的に操作するためのインタ フェースを開発するために，人間の操作的な手動作を 3 次 元入力装置として取り扱うインタフェースを提案した．提 案システムは, 非接触型計測装置として多視点カメラシス テムを用いて，手形状を推定しバーチャルクレイを操作す るシステムである. システムを実装し，ユーザの操作的な 手動作で仮想空間中の粘土モデルを滑らかに変形できるこ とを示した．また，PCクラスタを用いてビデオレートの 粘土変形を可能にし，ユーザにストレスを与えないインタ フェースとなり得た．今後は接触判定の高速化と, 粘土の モデルをソリッドモデルにして，より実際に近い粘土変形 を目指していく予定である。また，ハードウェアパワーに 頼らずに, 手形状推定手法の高速化を図るためのアルゴリ ズム改良を行っていく予定である. 


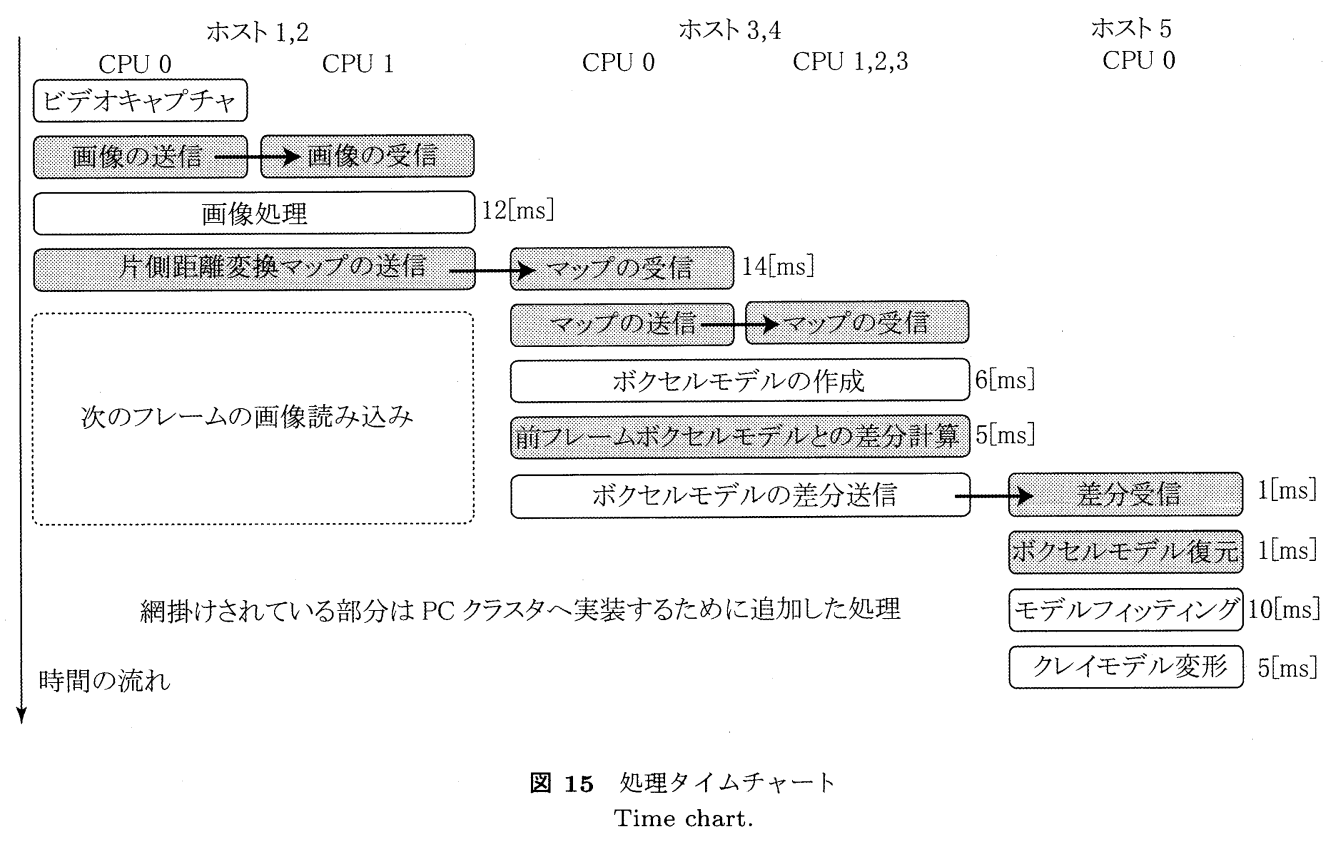

\section{[文 献]}

1) M. Matsumiya, H. Takemura, N. Yokoya. "An immersive modeling system for 3D free-form design using implicit surfaces". In Proc. of Intn' Conf. on Virtual Reality Software and Technology, pp. $6774,2000$.

2) Kevin T. McDonnell, Hong Qin. "Dynamic Sculpting and Animation of Free-form Subdivision Solids". In Proc. of Intn' Conf. Computer Animation 2000, pp. 126-133, 2000.

3) Gilles Debunne, Mathieu Desbru, Marie-Paule Cani, Alan H. Barr. "Dynamic Real-Time Deformations using Space \& Time Adaptive Sampling". In Proc. of Intn' Conf. Siggraph 2001, pp. 31 $36,2001$.

4) Francis K.H. Quek. "Eyes in the Interface". International Journal of Image and Vision Computing, Vol. 13, No. 6, pp. 511 525, 1995.

5) Richard Szeliski. "Rapid Octree Construction from Image Sequences". CVGIP:Image Understanding, Vol. 58, No. 1, pp. 23 $32,1993$.

6) Etsuko Ueda, Yoshio Matsumoto, Masakazu Imai, Tsukasa Ogasawara. "Hand Pose Estimation for Vision-based Human Interface". IEEE Transactions on Industrial Electronics, Vol. 50 No. 4, pp. $676684,2003$.

7) Edward Catmull, James Clark. "Recursively Generated B-spline Surfaces on Arbitrary Topological Meshes". Computer Aided Design, Vol. 10, No. 6, pp. 350 355, 1978.

8) William M Hsu, John F. Hughes, Henry Kaufman. "Direct Manipulation of Free-Form Deformations". In Proc. of Intn' Conf. Siggraph 1992, pp. 177-184, 1992.

9) N. Shimada, K. Kimura ,Y. Shirai. "Real-time 3-D Hand Posture Estimation based on 2-D Appearance Retrieval Using Monocular Camera". In Proc. Int. Workshop on RATFG-RTS(satellite WS of ICCV2001), pp. 23 30, 2001.

10）ウ 小軍, 東海彰吾, 和田俊和, 松山隆司。“PC クラス夕を用いた身体動作 の実時間 3 次元映像化”. 情報処理学会研究報告, Vol. 2000-CVIM-121, pp. $6572,2000$.

11）有田 大作, 濱田 義雄, 米元 聡, 谷口 倫一郎. “PC クラスタを利用した実 時間並列画像処理環境 RPV”。電子情報通信学会論文誌, Vol. J84-D-II, No. 6, pp. 965 975, 2001.

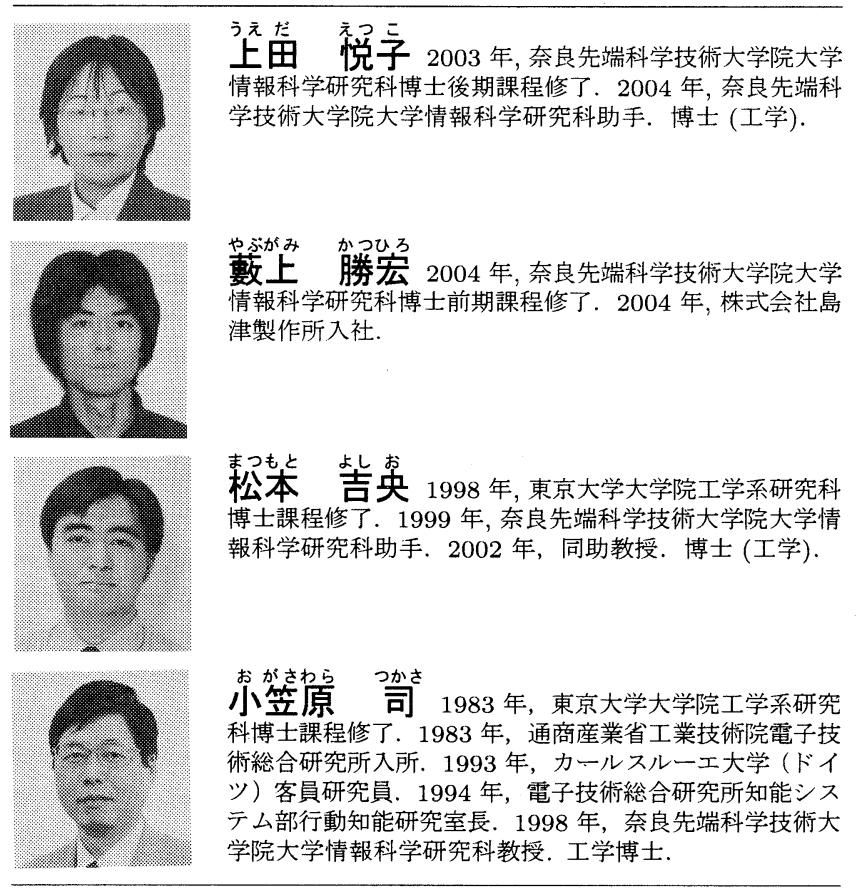

